\title{
Individuation in The Seventh Day of Creation: A Jungian Analysis \\ https://doi.org/10.33806/ijaes2000.21.2.11
}

\author{
Abdollah Hosseini, Soghra Falahati and Zahra Izadi, \\ Kharazmi University, Iran
}

\begin{abstract}
Jung's individuation process is associated with the shadow, anima, self, sage, and persona archetypes, during which the protagonist achieves self-discovery and selfawareness. Abdel Khaliq Al-Rikabi's The Seventh Day of Creation is one of the most popular Arabic novels in the twentieth century which has postmodern techniques including polyphony and time travel to present two main distinct narratives. If these intertwined narratives are considered separately, one can detect therein the archetypes informing Jung's idea of individuation. Most notably, the function of these archetypes in advancing the author's goal, which is a kind of self-discovery and creation of the novel, could be recognized in the novel's first narrative, namely, Kitab Al-Kotob (Sirah Al-Zatiyeh). The psychological analysis of this narrative shows that the author encounters unconscious archetypal elements such as shadow, anima, and sage; toward the end of the process of individuation, he becomes aware of how the form and content of the narrative are created. The first story is Sirah Al-Zatiyeh which presents the process of self-discovery of the author himself, undergoes the process of individuation in order to collect the manuscripts of Rawouq. In a three-step process, the novel's protagonist sets out on a symbolic journey to know himself and achieve self-discovery, after encountering the archetypes of the shadow (Badr and the poet), the anima (Warqa), and the sage (Shabib).
\end{abstract}

Keywords: Abdel Khaliq Al-Rikabi, archetype, individuation, Jung, The Seventh Day of Creation.

\section{Introduction}

Archetypes act as the joints and elements that make up literary works, and a large part of a literary structure includes them. Regarding the importance of archetypes in literature, Northrop Frye argues that a poet's mindset follows such exemplary forms (Frye 2008: 118). It seems that archetypes, partly, account for the survival of great works of imagination. Abdel Khaliq Al-Rikabi's The Seventh Day of Creation, a masterpiece of contemporary Arabic literature, abounds in national and global archetypes as well as references to great world epics. In the introductory part of thenovel, Al-Rikabi alludes to the content and form of the work and quotes from Ibn Arabi ${ }^{1}$ that "The world is a manuscript composed in the parchment of the publishedexistence, and its writing never ends" (Al-Rikabi 2009: 29). He, then, goes on to adda statement by Jung: "Learn as much as you can about symbols, then forget all of itwhen you are dreaming" (Al-Rikabi 2009: 29).

This novel and two other works by Al-Rikabi--Al-Rawouq and Qabl an Yahloq Al-Bashiq-- form a trilogy of Iraqi history: Al-Rawuq (Pure Water), 1986, Qabl an Yuhalliq Al-Bashiq (Before the Bashiq Flew), 1990, and Sabi Ayyam AlKhalq (The Seventh Day of Creation), 1994. The trilogy is epical, a grand history 
of Iraq from the 17th century to date. Despite the similarities in characterization, TheSeventh Day of Creation has taken a completely different path in terms of form andcontent. In this regard, Ahmad posits that "This novel completely deviated from this path, even though its structure is established on the basis of the previous two stories, in particular Rawouq manuscript, and includes a number of characters fromthe previous narrative" (1998: 119).

As one of the top twenty Arabic narratives in the twentieth century listed by the General Union for the Arabic Book in Damascus, this novel won the award for the best Iraqi fiction in 1995 and has been also translated into Mandarin Chinese (Shahab Ahmad 2016: 9). Al-Rikabi received his bachelor's degree from the College of Arts, Baghdad University in 1970 and has engaged in various professions such as teaching and the chief lexicographer in Afagh Arabiyyah magazine. He has been a member of the Literary Union as well as the Society of Artists and the Artists Association (Sakhou Al-Saidi 2003: 361). He composed twoplays entitled Al-Bizar and Naharat Al-Layali Al-Alif. Nafezat Besa'at AlHelm (1978), Ma Yaftah Bab Al-Telesm and Mokabedat Abdullah Asheq (1982), Al-Rawouq (1994), Atras Al-Kalam (2002), Sefer Al-Sarmadiya (2005), and Lily BabaAl-Hazin (2013) are among his other works of fiction (Karim Ati 2012: 7). Al-Rikabi's The Seventh Day of Creation demonstrates high potential for being read through psychological and archetypal criticism. It has often been analyzed in termsof postmodernism and Sufism as well, but this study seeks to articulate the processof the author's individuation and explore the Kitab Al-Kotob and the story collectionof Rawouq by the author. To this end, the following questions are also raised:

1. What are the most important archetypes that shape the narrative of SirahAl-Zatiyeh in The Seventh Day of Creation?

2. How do the archetypes of the narrative of Sirah Al-Zatiyeh affect the author's individuation?

\section{Review of Literature}

So far, a huge body of research has been conducted on The Seventh Day of Creation, most of which have adopted postmodernist and Sufi approaches. The notable examples are as follows:

In his "The Narrative of the Seventh Day of Creation by Abdel Khaliq AlRikabi: an investigation and analysis of the basic elements," Karim Ahmad Jawad Al-Tamimi and Adawiya Al-Gharwai (2002) explores the work's characters, narrative, dialogues, time, place, plot, language, and context.

Abbas Abd Al-Jasim (2012) examines the structure and style of the book by using a postmodernist approach. He finally concludes that Al-Rikabi's fiction is oneof the most successful examples of a postmodern work.

In "Artistic Awareness in Contemporary Iraqi Novels and the Cultural Heritage in the Narrative of the Seventh Day of Creation by Abdel Khaliq Al-Rikabi" (published in volume 4 of the 16th issue of the Fosoul Journal), Abdullah Ahmad (1998) analyzes the similarities and differences between Al-Rikabi's three novels, known as Salathiye Rawouq. He also points to the structural influence of Ibn 
Arabi'sFusus Al-Hakam and Jili's Ensan Al-Kamil fi Al-Akhar and Al-Awal on The SeventhDay of Creation in the fictional writings mentioned above

In his doctoral dissertation presented submitted to at Al-Haj Le-Khezr University (Algeria), entitled "The Presence of Sufism in the Contemporary Arabic Narrative Discourse," Abdul Rashid Hamisi explores Sufism in The Seventh Day of Creation and praises the book as one of the best examples of a Sufist writing. In "The Effect of Time on Developing a Semantic Structure in the Narrative of the Seventh Day of Creation," Hassan Karim Ati (2012) studies the function of time inboth narratives of The Seventh Day of Creation and uses tables and diagrams toillustrate in detail the temporal dimension of all the events in both parts.

In "The Narrative of Postmodernism in The Seventh Day of Creation as the Initiator of Action," Sami Shahab Ahmad (2016), in addition to elaborating on the significance of the main title and the sub-title of the book, examine the novel in terms of metanarrative, contradiction, addressee, and narrator.

In "Semiology of Destruction and Creation," Tarad Al-Kabisi focues on the form of the text, its contradictions, open ending, and other structural issues. It should be noted that this article was appeared at the beginning of The Seventh Day of Creation, reprinted in 2009.

In addition to the studies noted above, there are other pieces of research that analyzed this novel. However, no studies tackled the novel through the lens of mythological and archetypal criticism. Using a descriptive-analytical method and an archetypal approach, this study examines the process of the novelist's individuation in Sirah Al-Zatiyeh, one of the two narratives of The Seventh Day of Creation. It can be argued that the concept of perfect man is the main idea of the novel, a point which the preceding studies have also highlighted: "There are Sufism, power and weakness (Mottahari 2005: 127-145). All these views are based on the concept of "ego". The analytical Jungian psychanalysis, in terms of putting forward the concept of individuation, bears close relationship with earlier views on the perfect man concept as the individuation process is focused on archetype. "Ego" is the most archetype in relation to human perfection. Myths are equipped with characteristic features like "generality, potentiality, acquisition, variability and relativity" (Bagheripour 2010: 161). Moreover, this archetype includes individual and social features. A Jungian study of the novel is beneficial to identify the individual and social evolution in the two narrative lines of the fiction. In other words, in terms of focusing on his personal aspects in first narrative line, Abdel Khaliq Al-Rikabi takes it for granted that individual evolution is conducive to social evolution. Through introducing the idea of imperfection, he frees evolution from the confines of time and space.

\section{The Seventh Day of Creation: Synopsis}

The first narrative, entitled Asfar and written with the letters of the word 'AlRahman', presents the story of an author who, in order to write a book about Rawouq, searches all the libraries in the city of Al-Aslaf ending up visiting a library in the museum. The director of the museum, Badr Farhoud Al-Taresh, is a person with a vague background, who is enthusiastic about collecting historical artifacts 
and everything related to the past. His interest in history is such that his museum isbuilt as it is a Babylon Fortress. It is intertwined and twisted in a way that the museum is on the ground floor and the library is on the top floor. Already familiar with the author's books, Badr promises to cooperate and allows the author to explore the manuscripts in the museum library. In the library, the author meets a girl named Warqa, the receptionist, and is attracted to her beauty and high culture. On the other hand, by encouraging the author to use the method of recording the events of Sirah, Badr seeks to help him to write Rawouq accurately. He takes the author to visit Shabib Tahir Al-Ghias, who is one of the narrators of Rawouq ${ }^{2}$ and has done extensive research on this topic. Shabib, who is acquainted with the author through his books, provides him with his unfinished research on Rawouq. Shabib's research has not been fruitful due to some issues, including the absence of Al-Sayyid Noor papers. Additionally, by lending the author the original version of Universal Man by $\mathrm{Jili}^{3}$, he makes a great contribution to understanding the papers of Zakir alQayyim, such that the author appreciates it and regards Shabib as the main character of his story. The author's friend and colleague, called 'the poet,' exchanges views with him as the book progresses. The poet's practical help in arranging the author'sworking hours at the school is decisive where they both work. Warqa also takes themain step toward completing the narrative by finding the lost papers of Al-Sayyid Noor. Having become interested in the author during this period, Warqa symbolically expresses her infatuation by circling the letters in Al-Sayyid Noor papers in a way that this phrase "When will you understand?" emerges. After realizing Warqa's feeling toward him, the author goes to visit her the next day and prefers to meet her outside the museum. The story ends with the author and Warqa sitting on a bus as they are completing a full tour around the museum and the library (Shahab Ahmad 2016: 11-17). The individuation process of Abdel Khaliq AlRikabi, as the creator of the historical trio of Iraq and as a member of the Iraqi society, accentuates the beginning of self-discovery in the members of the Iraqi society and poses it as an initial step in social transformation and national identity. This point is presented in the second narrative line. "At the beginning of the second narrative line, Motlagh resorts to strangers to achieve power. He, in order to improve his rank, he starts to build a castle, an action which is opposed by AlSayyid Noor" (Wen-chin Ouyang, n.d: 7). Turning away from Al-Sayyid Noor's advices, exposes Al-Hashimah to all kinds of disasters, including plague. Although Motlagh survives the plague, he witnesses the death of his family and society. Realizing his shortcomings, he repents. He spends his life in giving service to others. He achieves leadership and sovereignty in Al-Hashimah by the citizens' vote. The rest of the story narrates the expansion of his family as the result of his sons' marriages. Tarash's marriage paves the way for him to access firearms, which strengthens their power to resist the tyrannical forces of the city. Those who refuse to pay taxes find themselves in clash with Al-Baladah forces. In the end, all Motlagh's sons are killed, with the exception of Tarash. 


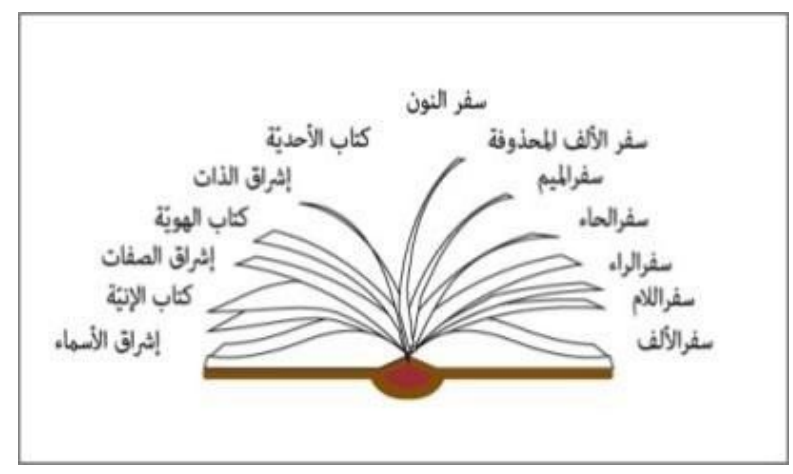

Figure 1. This figure shows the position of the first story, beginning with the title 'Asfar' in The Seventh Day of Creation

\section{Individuation}

Carl Gustav Jung (1875-1961), a Swiss psychiatrist, who collaborated with Freud to theorize psychoanalytic field for seven years, eventually established his own school: analytical psychology. Jung had a different understanding of libido and considered it as the life force (Payandeh 2019: 310). He also differed from Freud byextending his definition of the unconscious, while Freud believed each person's unconscious is unique. As Shamisa puts it, "In Jungian psychology, there are important terms such as the collective unconscious, introversion, extroversion, and archetypes, all of which are relevant to new topics in literary criticism, especially psychological and mythological criticism. He believed in two kinds of unconscious: personal and collective" (2006: 264).

According to Jung, "the existence of the collective unconscious means that no one's mind is a whiteboard and cannot be independent of different things that affect it. Indeed, in addition to the inevitable effects that the environment has on human beings, the human mind is strongly influenced by hereditary presuppositions. The collective unconscious includes the psychological life of our ancestors from their inception" (Jung 1975: 112).

Jung introduces the archetypal content of the collective unconscious as general and applicable to all human beings (Jung 1997: 6). The collective unconscious contains the structural elements that constitute a mythological system (Payandeh 2019: 313). The contents of the collective unconscious are not in the conscious mind, nor can be acquired individually, but can be inherited (Payandeh 2019). Although the origin of the archetypes is not known, they can be found in all eras and everywhere in the world (Jung 2008: 96). Literature, in this regard, is a staple of archetypes because it reflects human beings and their desires, aspirations, and problems, which are manifested in the form of positive and negative symbols, signs, and characters. The Seventh Day of Creation is an example of the representation of these archetypes. The theory of individuation is one of Jung's great contributions to psychology, which is related to the archetypes of shadow, persona, and anima. Individuation is a psychological development and basically a process of recognition; that is, one must consciously recognize the positive and negative 
aspects of one's psyche in the process of maturation (Guerin et al. 1992: 181).

If we consider both conscious and unconscious dimensions of personality, "Ego" will no longer be at the center but between the conscious and the unconscious; it will encompass the whole of existence and its name will be "Self" (Siasi 2009: 81). In some occasions, this is an unconscious process, such as a calf grows into a cow. However, it is self-conscious individuation which matters. In this process, the conscious must confront the unconscious in order to strike a balance between opposites. In self-conscious individuation, a large part of the darkness disappears to the extent that the personality is illuminated, and selfconsciousness is inevitablydeepened and expanded (Jung 2006: 234-235). Jung observes that an individual displays four types of action: sensory action (five senses), thought, feeling andemotion, and introspection and intuition. Most people are bent toward one kind of action. Many individuals with more complex personalities use two kinds of action, and distinguished people use three kinds of action. Practicing all four kinds of action is what Jung calls the process of individuation, which is indeed the adjustment of conflicting tendencies in a single nature (Najafi 2008: 57). This psychological rebirth, also called self-realization, is the process of individuation orbecoming a perfect human (Fist 2009: 146). In this course, firstly, the person has to adjust the persona that the conscious self wears to play social roles and is related to his/her collective identity. Secondly, he/she should remove its negative parts so that he/she is able to know the unconscious and acquire his/her personal identity. During the development of individual selfconsciousness, the protagonist is a symbolic possibility for ego to overcome the unconscious and free the individual from a regressive tendency toward a happy childhood (Jung 2008: 176). What is also necessary, a person should overcome the negative aspects of the shadow (Jung 2008: 176).

In the next stage, the protagonist of a fictional work should recognize the positive and negative animas to join the positive and avoid the negative ones. In stories read through the lens of mythical and archetypal criticism, the hero must pass tests in order to achieve his/her 'self'; victory in each stage means achieving unity and psychological integration. In an internal or external journey, depending on the type of story, the protagonist becomes familiar with his/her shadow and anima (animus). In this way, if a problem occurs, the archetype of sage enters the story. Looking at the protagonist's individuation in Al-Rikabi's The Seventh Day of Creation, the first narrative shows that the archetypes of shadow, anima or animus,persona, and sage have the most considerable impact on this process. Myths are constantly changing, and are based on human perception. Human mind using cognitive resources, which include assumptions and meanings, processes new information. Therefore, a text is the result of an interaction between old and new assumptions (Inas Mohamed Younis 2017: 32). As noted above, the mythical content of the novel can be decoded from a Jungian perspective. From the standpoint of Jung, mankind pushes a negative point to the marginal (shadow) point his/her life. The author knows that Rawagh is infested with impurities, and therefore dedicates this book to his shadow (Badr). Badr and Warqa are familiar with the 
contents of Rawouq whose assumptions and presumptions in the process of individuality are processed with the help of archetypes. In other words, in the first narrative, the content of Rawagh ${ }^{4}$ plays an important role in the writer's individuation process; in the second narrative, it plays an important role in shaping archetypes and myths. Myth (AL-Motlagh) is a symbol of the political leaders of Iraq, who initially looks at human evolution from the perspective of power and resorts to foreigners, but with the guidance of Al-Sayyid Noor and the problems that rise along his path, he achieves a kind of inner awakening. Thus, he pursues the interests of his people and is eventually killed in this way. Jungian analysis seems to suggest this kind of change in terms of evolution in the Iraqi political leaders.

\subsection{Shadow}

Shadow is one of the most remarkable archetypes introduced by Jung. The shadow signifies the negative aspect of personality, and refers to those unpleasant traits (selfishness, greed, love of material things, desire for power, and the like), which are incompatible with the rules and regulations of conscious life and the person constantly hides them. Shadow as an archetype is a factor in exposing the sinful tendencies of human beings and unpleasant behaviors, thoughts, and desires, as well as unfavorable social feelings (Jung 2008: 257-269). According to Jung, the shadow helps to polarize things, which is required for progress and development. $\mathrm{He}$ believes that humans need energy to perform mental activities. This energy is provided by the struggle of opposites. The human psyche is a collection of opposites that are constantly in conflict, and the task of an individual is to identify and balance these opposing forces. The degree of human perfection depends on the extent to which this balance is maintained (Siasi 2009: 60). Jung argues that the shadow has two aspects, one is terrible and the other is precious (Jung 2008: 264). Moreover, the shadow has a personal and a collective aspect, and includes some parts of the personal unconscious as well as the collective unconscious. The shadow is more than the personal unconscious, to the extent that it is related to the weaknesses and failures of the individual; it is personal, but once problems and complications are shared, they go beyond the confines of a person and transform into ethnic phenomena (Fordham 1995: 93-96).

In the narrative of Sirah Al-Zatiyeh, the author meets his shadow at the outset. Having experienced countless confusions and difficulties in finding the manuscripts, he finally goes to the library of Badr Farhoud Al-Taresh and expresses:"Thus I frequented the libraries year after year and finally reached the museum library" (Al-Rikabi 2009: 34). This statement serves as an introduction to the process of individuation. Badr, the owner of the museum and library of Madinah Al-Aslaf, reflects the characteristics of the negative shadow for the author. There are many rumors about the origin of his lineage. The unwavering support of a foreign man, who seems to have no [blood] relation with him, is the source of these words, and the blue color of his eyes reinforces the existing rumors. At the same time, He has benefited from the support of both this foreign person and his father's inheritance. 
The negative characteristics of the shadow are visible in different parts of the story. Badr sometimes discourages the author by bringing up negative points, such as where he finds it impossible to obtain the original version of Universal Man: "I'm telling you that it is impossible to access that version of the book!" (Al-Rikabi 2009: 267).

The shadow has positive aspects as well. Badr considers his love for history as the only pleasure in the world: "My only joy in this world is expressed in my love for history" (Al-Rikabi 2009: 255). He even bequeaths the rest of his wealth tobe spent along this path: "I wrote in my will that you should give a large part of my wealth to the museum after I die" (Al-Rikabi 2009: 255). He even has progressive views on art and innovation: "Everything is fleeting, except art and creativity" (Al-Rikabi 2009: 54). The similarity between the author and Badr is acknowledged byboth characters. Thus, the author expresses that "I feel that Badr and I have similarities in what we do; just as he tries to stop the passage of time through archeological specimens, I do the same but through words" (Al-Rikabi 2009: 311). Badr also points to their common goals: "How can I ignore the museum and that manuscript when they are in fact two aspects (place and time) of our past history?!"(Al-Rikabi 2009: 44).

In the course of individuation, the author strengthens his relationship with Badr. He gives Badr a copy of his latest book with words that are not devoid of humor: "(Dedication) to Master Badr Farhoud Al-Taresh ... without retouching ... or embarrassment" (Al-Rikabi 2009: 40). In this way, their relationship becomes more intimate as Badr comes to the author's house and even discusses with him about the details of the new book he intends to write. These conversations lead the author to accept Badr's suggestion for the open ending for the book. The interaction between Badr and the author results in their shared journey of individuation, in a sense that Badr himself takes the lead in collecting Rawouq: "Without you asking, I have recorded the third part of Sirah Al-Motlaghiyyah for you to justify your idea that each of us completes another's work" (Al-Rikabi 2009: 320). But toward the end, the presence of the shadow in the narrative diminishes to the point that the author, in contrast to his usual habit, postpones visiting Badr to after meeting Warqa: "Contrary to my habit of first stepping into Badr's room, I went to the museum ..., and I will certainly be blamed for violating friendship protocols" (AlRikabi 2009: 376).

Referring to Jung once again, in some of his works, he introduced the wise old man (sage) as a positive shadow. Jung views the positive shadow as the embodiment of a sage and, the devil as one of the ancient forms of the dangerous aspect of the dark and unknown part of the mankind, namely, the shadow (Jung 1992: 133). The presence of the poet, who is a friend and colleague of the author, might symbolize the positive shadow. He encourages the author and plays a positive role in the process of collecting Rawouq: "I will oblige you to write your story, even if it is necessary to seek the help of the police ... the creativity police, of mean" (Jung 1992: 275). 


\subsection{The sage}

The sage is the manifestation of knowledge, meaning, and life. He represents insight, wisdom, intelligence, and enlightenment; he also has moral qualities such as a strong will and readiness to help others, which turn him into a spiritual and pure character, popular among people (Guerin et al. 1991: 178). In stories and dreams, the sage appears when the protagonist is in a difficult and inevitable situation. This is where an insight or creative thought, a spiritual action or a kind of spontaneous inner and psychological action, can save the protagonist from trouble; however, he is not able to achieve it himself due to internal and external causes. At this time, the knowledge required to compensate for deficiency is manifested intellectually, that is, in the form of a sage and helper (Jung 1989: 114). In The SeventhDay of Creation, Shabib Tahir Al-Ghias fulfills the functions of being a sage. His teacher, Mamdouh Afnadi, describes his knowledge of narratives as: "Although hewas over fifteen years of age when I started teaching him to read and write, in a short period of time he was able to read One Thousand and One Nights over successive days during which he nearly lost his sight" (Al-Rikabi 2009: 50). Shabib was highly respected by the people of Al-Aslaf, such that he had acquired the title of Abqari Al-Aslaf: "Venerating Shabib Tahir Al-Ghias has become one of the city'straditions. It earned him the title of the "Genius of the Past," which he truly deserves" (Al-Rikabi 2009: 44). These words suggest the knowledge of Shabib. In The Seventh Day of Creation, Shabib's contribution in collecting Rawouq issignificant. He helps the author in various stages of collecting the manuscripts, because he himself has already carried out some research on the same project, but his attempts have not borne fruit due to numerous defects and distortions in the existing versions of Rawouq.

His first assistance is to provide the author with a background on Rawouq: "As long as he helps you write the narrative, he will not fail to provide you with what he has done in recent days and weeks" (Al-Rikabi 2009: 132). He allows the author to use the results of his studies: "I gave you what I wrote to you" (Al-Rikabi 2009: 137). Shabib continues to help and he does not hesitate when the author needs the original version of Jili's Universal Man: "Take this ... you can keep it with you for as long as you wish" (Al-Rikabi 2009: 272). In the process of individuation, the sage leaves the stage after the protagonist reaches his desired state. In Al-Rikabi's novel, Shabib dies after the lost papers of Al-Sayyid Noor are found, and the recitation of Surah Al-Rahman in the funeral ceremony implies the completion of Rawouq: "He recited Surah Al-Rahman in a glorious and steady rhythm, and his voice was powerful, moving, and awe-inspiring" (Al-Rikabi 2009: 392).

\subsection{Persona}

Persona is an aspect of personality that is shown to the world. This archetype is like a literal mask that is put on or is a public appearance that one assumes in order to show oneself in a different way from what he/she really is (Schultz 2011: 122). Persona is a necessity through which we communicate with our world, and it regulates the relationship between the individual and society. Human civilization 
requires the individual to compromise with society and this need is partly fulfilled through persona. Compared to other archetypes, it has a stronger social dimension, although it does not lack individual aspects (Fordham 1995: 50-51). Like other archetypes, persona is two-sided and can appear in useful and positive or negative and dangerous forms. While it is an essential aspect of human personality, one should not equate it with himself/herself. If people imitate their masks in an extreme way, they become unmindful of their individuation and abandon the process of self-realization (Schultz 2011: 128). Jung believes that mental health presupposes a balance between the demands of the society and the real personality of its citizens. Of course, being unaware of persona means underestimating the importance of society, and being unaware of individuality makes a person susceptible to manipulation by society (Schultz 2011: 128). According to Jung, achieving perfection and individuation is only possible when a flexible persona is adopted, to the extent that it could be attuned to a range of regular and harmonious relationships with other components of the psyche (Rastegar-Fasaei 2009: 214).

In The Seventh Day of Creation, the author appears in society through the persona of a teacher and a writer. He does not immerse himself in this role. In contrast, he frees himself from being assimilated into his role thanks to the intellectual support he receives. During his journey, the author realizes that he is not a historian but simply a narrator: "I am not a historian to link the fate of my narrative to these sources, even if I realize that these sources strengthen and improve my narrative" (Al-Rikabi 2009: 268). He also easily interacts with his persona and makes it flexible. The author works at a school where he can ask his friend - the poet - to perform his teaching duties and thus buy time to do the research: "At school, I reduced my working hours as an art teacher. Painting lessons are the last thing students do, and I left it to my friend to ... teach Arabic" (Al-Rikabi 2009: 47). In this way, the author seeks various excuses to provide more hours for individuation: "I read it carefully these days, and in the meantime I used various excuses to run away from school" (Al-Rikabi 2009: 19). During the process of individuation, with the help of his poet friend, the author adjusts the persona to the point of removing it, which is where the narrative is completed. This takes place when the author forgets his social role in meeting Warqa: "So I remembered my school, which had been absent from my mind until that moment" (Al-Rikabi 2009: 40).

\subsection{Anima and Animus}

Anima or the female twin is one of the most important archetypes in the collective unconscious. In fact, anima is the archetypal image of the ideal woman in the male unconscious, and animus or the male twin is the archetypal image of the perfect man in the female unconscious. Jung considers this archetype to be the vital force in the psyche that prompts human beings to action. For him, every person's psyche is bisexual. In other words, every man has a feminine face and every woman has amasculine face too (Payandeh 2019: 317). Jung is skeptical about this idea and saysthat anima may be the psychological expression of the minority of female genes inthe male body (Jung 1991: 50). The man tends to project his anima onto 
his wife or mistress and see her not as she is, but as unconsciously determined by his individualor collective unconscious (Fist 2009: 129-130). Performing things requires energy, and the process of individuation is of no exception. In this case, that energy is obtained from the principle of opposites. It is one of the most important foundations of Jung's theory of individuation. In the human psyche, there is a set of opposites that are constantly in conflict with one another. It is the duty of a person to recognizethese opposing forces and to establish a degree of balance and proportion betweenthem (Siasi 2009: 60). The importance of this awareness and recognition is to the extent that neglecting it makes the selfdiscovery principle impossible to obtain. InJungian psychology, the relationship between consciousness and unconsciousness is the relationship between masculinity and femininity, and the self arises from theintegration of these two disjointed halves. If this transformational archetype is not activated and does not send its call, which is aimed at achieving unity and oneness, to the realm of the conscious self, the two sides of the psyche will remain separateand unaware of each other; therefore, no perfect self will be formed (Yavari 2008:125).

At the beginning of the process of individuation, the author's goal of collecting Rawouq (symbol of self-discovery) is self-love: "In any case, I can only accept that writing narratives is really nothing but a kind of self-love" (Al-Rikabi 2009: 32). But this goal is sublimated over time, and he seeks a special meaning for [his] existence, which he finds in Warqa: "I write so that Warqa might love me" (Al-Rikabi 2009: 261). At the beginning of the process of individuation, for him, anima was a means of gathering Rawouq manuscripts, but eventually it becomes agoal. Jung considers the unity of opposites as both a goal and a means of individuation (Sattari 2007: 412). Warqa has a strong presence during the collection of Rawouq. She makes considerable efforts to find the missing piece of Al-Sayyid Noor, and Badr talks about her efforts thus: "In fact, she is the one behind the preparation of these manuscripts for you" (Al-Rikabi 2009: 376). Over time, the author's feelings do not remain one-sided, and Warqa also gets attracted to the author. Every night under the pseudonym of Ilham [literally meaning 'inspiration'], she telephones the author when he is not in the library. Regarding these calls, the author says: "The beginning of her relationship with me is astonishing; after I persuaded her to exchange some words with me, albeit as short as a good afternoon greeting, she took refuge in the songs out of embarrassment so as to express her feelings" (Al-Rikabi 2009: 326). But at the end of the process of individuation, shedeclares her love to the author in writing and in a cryptic way by circling the lettersof the words found on the pages of Al-Sayyid Noor in an attempt to show the question "When will you understand?". Warqa continues to reveal herself to the author in different ways; she tells the author that she is one of the main characters of his new story: "Have I ever told you how I feel about being one of the charactersin the story?" (Al-Rikabi 2009: 328).

The author finally realizes that Elham is the same girl as Warqa because of the fact that she repeats the question "When will you understand?" 


\subsection{Encountering the self}

According to Jung, the self is the most general archetype that can be achieved only if a balance is established between opposing forces and they are proportionately integrated (Fist 2009: 118). The human psyche has two parts, the conscious and the unconscious. The latter is divided into two types, personal and collective. The conscious self is actual and the Ego is at its center. The collective unconscious is the potential part of the psyche and the reserve of archetypes that are manifested inthe personal unconscious. If we consider the elements of human personality and mental structure as several intertwined circles before unification, the innermost circle, the middle circle, and the outermost circle will be collective unconscious, personal unconscious, and consciousness, respectively. According to Jung, Ego is the center of consciousness not personality, because consciousness does not constitute all personality but only a proportion of it. Gaining access to one's self ispossible through the process of individuation. In this process, the elements of personality are integrated and the conscious and unconscious dimensions of an individual are united (Payandeh 2019: 316). This self-discovery is possible when the constituent elements of personality have grown enough, at which stage the center of personality is transferred from the conscious self to an area between the conscious and the unconscious (Siasi 2009: 81). In the process of individuality, the realm of self-consciousness expands by dominating the forces of collective unconscious, and its strength boosts by absorbing the powerful themes of the unconscious. Self-realization requires having goals and plans for the future and an accurate understanding of one's abilities (Fist 2009: 124).

In The Seventh Day of Creation, self-discovery culminates with the emergence of tangible effects in all four types of the author's actions. These effects could be examined in terms of senses, thought, emotion, and intuition.

\subsubsection{Self-discovery in senses}

At the beginning of the story, the author describes his sensory perceptions, but these senses are not fully utilized. He refers to the voice of the muezzin of al-Aslaf city when he opens the windows: "From its window I could see dozens of minarets, all of which were illuminated with the name of Allah" (Al-Rikabi 2009: 34). He does not forget to express his sense of smell: "The almost dark atmosphere is filled with the scents of incense and henna" (Al-Rikabi 2009: 35). And he senses the smell of pen and ink in libraries: "...the smell of paper and printed ink that I could hardly sense until I lowered my head in reverence" (Al-Rikabi 2009: 34). He also talks about his sense of sight in his first meeting with Warqa: "Here the lack of light does not allow studying facial features" (Ibid, 34).

\subsubsection{Self-discovery in thought}

The author's thoughts are not developed in the beginning. He has many doubts about the form and content of the book he intends to write. The reason is that there is no precise method for writing the book despite the many manuscripts of Rawouq, its many narrators, distortions, and defects. He considers himself as a stonemason who has failed to create his desired work: "I'm like the Florentine sculptor who said that 
the statue is in the heart of the rock and all he had to do was remove the shells from it" (Al-Rikabi 2009: 188). Therefore, Shabib, Badr, and his poet friend help him in'sculpting' the narrative. After conducting extensive research, he realizes that thereare many flaws and distortions in the manuscripts of Rawouq. On the other hand, because he does not want his efforts to have the same fate as Shabib's, he changes his goal and supposes that it is impossible to collect Rawouq: "Naturally, my purpose is not to collect Rawouq, because I am sure it is impossible ... My purposeis higher than Rawouq and I am going to write a narrative about it" (AlRikabi 2009:382). He begins the narrative by using the so-called wejadah ${ }^{5}$ method, which he borrows from Shabib's research. As an act of appreciation, the author chooses Shabib as one of the main characters in his work: "I in turn used the pages of ZakirAl-Qayyim in a method called "Al-Wajadah... and so it was crystallized for me in its final form, through which the contents of the new text were presented. I

rewarded (Shabib) only in a way that would make him happy. I made him not only an important person but the main hero of the story, (so) that the existence of the new text of Rawouq depends on him" (Al-Rikabi 2009: 271). Shabib's contributionsare not limited to proposing a formal idea; indeed, he provides the author with Universal Man by Jili, which is effective in determining the content of the narrativeas well. This is because the subject of identity is one of the sections of Jili's work and it corresponds to the content of Zakir Al-Qayyim's book: "It is a precious copyof the book that inspired the content of this narrative" (Al-Rikabi 2009: 273).

The stages of the exit and movement of essence towards existence are mentioned, and these stages are effective in shaping the structure of the book: "From that night on, the structure of the narrative was crystallized for me; by chance, these white pages were in a place where the content in the original manuscript refers to the three stages of the movement of essence to the realm of existence. It was then (I decided) that the characters in my story should ascend toward the author and the author should descend toward them" (Al-Rikabi 2009: 387). Badr is also influential over the formation and consistency of the narrative. He points to a fact called 'the flaw in creative works,' which can be observed even in the museum he has built: "It is because of a vague feeling that every creator seeks perfection in his work; it is a feeling of inadequacy that is unavoidable" (Al-Rikabi 2009: 43). The author of a story about the history of a famous city (Al-Aslaf) and the creator of a work in which thousands of people are involved would think of more than just one story; he remembers that the publication of One Thousand and One Nights had been a barrier to the expansion of its content and subsequent additions: "Like your dream of establishing your own world museum, I also had an impossible dream. My dream was that some of the manuscripts would be exempt from publication, and that is because I sometimes feel that not all scientific inventions are useful for humanity" (Al-Rikabi 2009: 258). Therefore, he decides tochoose an open ending for his narrative so as not to delimit the meaning of his writing: "An open text in which there is no (semantic) boundary" (Al-Rikabi 2009: 117). He also exploits new writing techniques such as the polyphonic style ${ }^{6}$ : "What 
brings them together is the modern style of the novel; Bakhtin said the novel uses a combination of methods and the language of the novel is an array of languages" (Al-Rikabi 2009: 189).

\subsubsection{Self-discovery in feeling}

The author encounters multiplicity in the realm of emotions: on the one hand, he loves Warqa and writing is not his only goal; but on the other hand, he listens to the phone messages of a girl who introduces herself as Elham and is not able to focus all his emotions on Warqa: "Of course, I could put an end to this nonsense by hanging up the phone, but curiosity overcame me" (Al-Rikabi 2009: 268). But at theend of the story, where the act of individuality culminates, the author reaches his perfection by deploying all the actions of the psyche in the rigorous test of individuation. The process of individuation transforms the author's thoughts. He disposes of all available forces to compose Rawouq, and he attains this power when he becomes aware of Warqa's love for himself and realizes that she is the same girl who called him every night under the name of Elham. This is the beginning of intuition and discovering the truth for the author: "I did not find out this (truth) until I slapped my forehead because of the shock of this discovery ... I mean, is Elham the same person as Warqa?" (Al-Rikabi 2009: 397). This revelation explains the strange behaviors of Warqa for the author: "I finally figured out the secret of Warqa's escapes" (Al-Rikabi 2009: 397). Loving Warqa inspires a motion in the author that causes him to move from his conscious to his personal unconscious, which is dusty due to negligence: "I went to the ground floor and entered the house. Because of my negligence, my footprints weighed heavily on the carpets. Dust was spread everywhere" (Al-Rikabi 2009: 398).

\subsubsection{Self-discovery by intuition}

The Seventh Day of Creation illustrates the effect of the intuitive dimension of individuation through spatial movement due to its intangibility. In this narrative, the process of individuation occurs in places that can represent the author's mind. The events of the story happen in two main places: the author's house and the museum of the city of Al-Aslaf. The house where the author lives has two floors and he spends most of his time on the second floor. The equipment in this room signify the awareness that is available to him and is related to his present. But the lower floor of the house, where the walls of the rooms are decorated with pictures of his family members, evokes his personal unconscious and childhood memories. The museum and library of the city of Al-Aslaf symbolize the collective unconscious, where the author can access to all the information of the past, and by moving between these two places, he can complete the process of individuation.

Jung's statements about the nature of the unconscious reinforce these suggestions. Thus, he says the mind, just like the body, is a museum that exhibits the history of human evolution (Jung 1939: 24). At the end of the narrative, the passion for recognizing Warqa is materialized in the symbolic movement of the author from the upper floor of his house to the first floor. The author transfers this love from his personal conscious to his personal unconscious and tries to maintain 
it. The love of Warqa penetrates the personal unconscious of the author so deeply that he likes to engrave her name on the dust: " ... it was covered with a thick layer of dust, and I was tempted to write the name of Warqa with the tip of my index finger, this beloved name that I wished I could have written on every wall of the house" (Al-Rikabi 2009: 398). Warqa triggers the author's unconscious activity, for example, awakening his childhood memories, and prompts sensory actions simultaneously: "Between these distant memories, ... there are dozens of memories whose forms, sounds, smells, and lights overlap in my mind" (Ibid, 399). In addition, Warqa causes the author to use the sense of touch by writing the first title of Kitab Al-Kotob (Sirah Al-Zatiyeh), that is, the genesis creation narrative Al-Alif, and explains the general plan of the book: "Below my pen is the first white sheet to write the title ofthe first part of this new narrative of Rawouq, which has already been narrated by six people before me in such a way that the seven letters of the name Al-Rahman ${ }^{7}$ flow in one form in the order of these numbers" (Al-Rikabi 2009: 399).

Finally, the author's self-discovery ends in a place between the museum and his home, which is symbolically between the personal unconscious and the collective unconscious. When individuation ends, the sage leaves the scene and Badr's presence diminishes; furthermore, by removing the persona, the author reaches unity with the anima and the movement from Ego to Self is completed. Meanwhile, according to Jung, individuation never ends for common people, which is reflected in the story as the bus carrying the author and Warqa passes around the museum: "And (the bus) had made a full turn around (Tal Al-Arbaeen)" (Al-Rikabi 2009: 402). This rotational motion reminds us of the archetype of circle, which can rotate forever since it has no angle (Payandeh 2019: 326).

\section{Conclusion}

As has been shown, the first story of The Seventh Day of Creation, namely, Sirah Al-Zatiyeh, narrates the process of self-discovery of the author Abdel Khaliq AlRikabi, which takes place in places that signify different parts of his mind. In this narrative, the author, who is a writer and a teacher, sets foot on the path of individuation for the purpose of collecting the manuscripts of Rawouq. After much trouble and confusion, he enters the museum of the city of Al-Aslaf, which symbolizes the collective unconscious. In a three-step process, the novel's protagonist sets out on a symbolic journey to know himself and achieves selfdiscovery after encountering the archetypes of the shadow (Badr and the poet), the anima (Warqa), and the sage (Shabib).

Badr and the poet take significant steps to modify the social persona of the author (namely, writing) thanks to their shadow function. Shabib, serving as the sage, helps to untie the knot of the narrative with his timely appearance. Moreover, by finding the missing part of the narrative, that is, Al-Sayyid Noor papers, the author's anima (Warqa) accelerates his individuation process. At this point, it is the author'sturn to put the data of the problem together and solve the riddle. By knowing his own anima and joining her, the author uses all kinds of his human actions and achieves identity and self-knowledge somewhere symbolically 
between his personal unconscious and the collective unconscious.

\author{
Abdollah Hosseini, \\ Kharazmi University, Iran \\ ORCID Number: 0000-0002-3960-0690 \\ Email: dr.abd.hoseini@,khu.ac.ir \\ Soghra Falahati \\ Kharazmi University, Iran \\ ORCID Number: 0000-0002-7272-4177 \\ Email: falahati@khu.ac.ir \\ Zahra Izadi \\ Kharazmi University, Iran \\ ORCID Number: 0000-0003-3194-7371 \\ Email: $\underline{\text { izadiii.79@gmail.com }}$
}

\title{
Endnote:
}

${ }^{1}$ Mohi-ud-Din Ibn Arabi, nicknamed Shaykh Al-Akbar, was born in Murcia, Spain, in July1165 and died in November 1240 in Damascus. He was buried at the foot of Mount Qasioun.Two of his works, Meccan Revelations and The Bezels of Wisdom, made him one of the greatest Muslim Sufis (Nicholson 2001: 404).

${ }^{2}$ In The Seventh Day of Creation, Rawouq is a manuscript with six narrators. Three of these people, named Abdullah Al-Basir, Madloul Al-Yatim, and Azib Al-Asheq, have narrated itorally; and the other three, namely Al-Sayyid Noor, Zakir Al-Qayyim, and Shabib Tahir Al-Ghias, have rendered it to its written form (Al-Rikabi 2009: 251).

${ }^{3} \mathrm{Abd}$ Al-Karim Gilani or Jili, nicknamed Qutbuddin, is one of the great figures in mysticism and Sufism and the author of the famous book Universal Man, the content of which is philosophical mysticism (Jili 2013: 24-26).

4 Zakir Al-Qayyam read the first chapter of Al-Sayyid Noor who wrote the work calligraphically with a style adorned with puns and rhyme. The first chapter is rife with the myths of Al-Mutlagh Dynasty (Al-Rakabi 1986: 9). It is important to mention this point inaccordance with Al-Sayyid Noor's intention in the first chapter, who as the author has not doubt its authenticity. The author has chosen this name for the chapter because of its similarity to a strainer which purifies water from contaminants (Al-Rakabi, 1986: 357). Despite the ubiquity of events, news, names, and concerns, this narrative has been collected in Al-Bawashiq era. It is a name of a nomadic tribe which has faced hardships for decades by successive governors. The tribe, however, has managed to maintain its originality, turned oppressions into lessons experienced by different generations. (Al-Rakabi 1986: 358)

${ }^{5}$ It means quoting a hadith from a book and based on recognizing the author's handwriting without hearing, reading, or permission (Shahid Thani, 2002: 43).

${ }^{6}$ Polyphony is a term originally derived from music and it forms the central concept of Mikhail Bakhtin's theory of dialogism. According to Bakhtin, due to the presence of polyphony, various ideological positions occur in literary works (Makaryk 2006, 101) 
${ }^{7}$ It should be noted that this word has seven letters in Arabic but eight letters in English. Identity and self-knowledge somewhere symbolically between his personal unconscious and the collective unconscious.

\section{References}

Al-Rikabi, Abdel Khaliq. (1986). Al-Rawagh. Baghdad: Cultural Affairs Publication.

Ahmad, Abdullah Ahmad. (1998). "Artistic Awareness in Contemporary Iraqi Novels and the Cultural Heritage in the Narrative of the Seventh Day of Creation by Abdel Khaliq Al-Rikabi" Egypt, Fosoul Journal.

Al-Rikabi, Abd Al-Khaliq. (2009). The Seven Days of Creation. Lebanon: Arab Foundation for Studies and Publishing.

Bagheripour, Ashraf. (2010). Jung and the psychoanalysis of religion. Tabriz: Philosophical Research.

Feist, Jess \& Gregory Feist. (1985). Theories of Personality. Maidenhead: McGraw-Hill.

Fordham, Frieda. (1970). An Introduction to Jung's Psychology. Baltimore: Penguin Books.

Frye. Northrop. (1990). Myth and Metaphor: Selected Essays, 1974-1988. Virginia: University of Virginia Press

Guerin, Wilfred. (2011). A Handbook of Critical Approaches to Literature. New York: Oxford University Press.

Jili, Abdul Karim. (2013). The Perfect Man in the Knowledge of the Late and the Early, translated by Seyyed Ali Hosseini Amoli. Qom: Ayatollah Ishraq.

Jung, Carl Gustav. (1939). The Integration of Personality. New York: Farrar\& Rinehart.

Jung, Carl Gustav. (1975). The Significance of Constitution and Heredity in Psychology: The Collected Works of C.G. Jung. Princeton: Princeton University Press.

Jung, Carl Gustav. (1979). Man and His Symbols. London: Aldus Books.

Jung, Carl Gustav. (1986). Four Archetypes: Mother, Rebirth, Spirit, Trickster. Princeton: Princeton University Press.

Jung, Carl Gustav. (1997). The Portable Jung. New York: Penguin Hooks. Jung, Carl Gustav. (2011). Answer to Job. Princeton: Princeton University Press.Jung, Carl Gustav. (2012). Psychology of the Unconscious. Dover Publications Inas Mohamed Younis. (2017). The Translation of the "Myth" of Crucifixion in

Kamel Hussein's Qaryah Zalima: A Relevance Approach, Lebanon,International Journal of Arabic-English Studies (IJAES).

Karim Ati, Hassan. (2012). The Effect of Time on The Seventh Narration of the Seven Day of Creation. Beirut: The Arab Foundation for Studies and 
Publication.

Mottaheri, Morteza. (2005). Perfect Man. Tehran: Sadra Publication.

Najafi, Reza. (2008). Hermann Hesse. Tehran: Karun.

Nicholson A., Reynold. (1907). A Literary History of the Arabs. Forgotten Books Payendeh, Hossein. (2019). Literary Theory and Criticism. Tehran: Samat Rastegar-Fasaei, Mansour. (2009). Sculpture in Mythology. Tehran: Institute of Humanities and Cultural Studies.

Rima Makaryk, Irene. (1993). Encyclopedia of Contemporary Literary Theory: Approaches, Scholars, Terms. Toronto: University of Toronto Press.

Sakho Al-Saidi, Abdel Fattah. (2003). Dictionary of Literature from the PreIslamic Age to 2002. Beirut: Dar Al-Kitab Al-Alamiya.

Sattari, Jalal. (2007). Sufi Love. Tehran: Center Publication.

Schultz, Duane \& Sydney Ellen Schultz. (2017). Theories of personality.

Australia: Cengage Learning

Shahab Ahmad, Sami. (2016). The narration of the seven days of creation. Oman: Dar Al-Hamed for publishing and distribution.

Shahid Thani, Zayn Al-Din bin Ali Ameli. (2002). Al-Bada'iyya in the science ofknowledge. Qom: Center Publication

Shamisa, Sirus. (2006). Literary Criticism. Tehran: Mitra.

Siasi, Ali Akbar. (2009). Personality Theories or Psychological Schools. Tehran: Tehran University Press.

Wen-chin Ouyang. (N.D). Abd Al-Khaliq Al-Rikabi; school of oriental and African studies, (University of London)

Yavari, Hora. (2008). Psychoanalysis and Literature. Tehran: Sokhan. 